\title{
Drought mitigation interventions of Krishi Vigyan Kendra for enhancing chances of successful harvest in rainfed areas of Satna district of Madhya Pradesh
}

\author{
R.S. NEGI ${ }^{1}$, S.S. KAUSHIK ${ }^{1}$, P.S. GURJAR ${ }^{1}$, A.K. SHARMA ${ }^{1}$ AND U.S. GAUTAM* \\ Zonal Project Directorate, Zone VII (ICAR), J.N.K.V.V. Campus, JABALPUR (M.P.) INDIA
}

\begin{abstract}
Drought is a major constraint to rain-fed crop production. Analysis of drought on the basis of rainfall pattern of Satna district revealed that the distirct experiences three types of drought in Kharif sown crops; early season drought, mid season drought and terminal drought resulting in seedling, pre-flowering and post-flowering drought stress. Post-flowering drought stress manifests in crop lodging, disease, reduced seed size, premature plant senescence and death of plants. In Satna district, rice, pigeonpea and soybean are the main crops grown during Kharif. Yield losses vary according to severity and the type of drought. Prolonged droughts at any stage results in crop failures. When crop fails farmer rely on relieve measures from governments and welfare organizations. Drought affects livelihoods of more than 1.46 lakhs families in the district. To minimise impact of drought, Krishi Vigyan Kendra have assessed and demonstrated drought mitigating technologies to increased chances of successful harvests. The technologies include varieties that escape/tolerate drought due to early maturity and drought management techniques. Short duration, drought tolerant, disease tolerant varieties of rice, pigeonpea and soybean have been demonstrated and promoted to address drought problem in the district particularly in areas receiving less rains and poorly distributed rainfall. The rice varieties IR-64 and IR-36 (maturing in 115-120 days) have been replaced by early maturing rice varieties JR-201, NDR-97 and Vandana; soybean varieties JS-335 replaced by JS-9305 and JS-9560: long duration pigeonpea varieties have been replaced by short duration ICPL-88039, TJT-501 and TJT-401 in rain fed drought prone areas. These varieties escape terminal drought because of early maturing. The early maturing crops like sesame, black gram, green gram and cowpea have also been introduced in drought prone areas. Further, the improved short duration, disease tolerant varieties are integrated with drought management techniques to reduce drought effects. Management techniques included water harvesting and moisture conservation techniques like ridge and furrow sowing, mulching, compost application, conservation tillage, planting time manipulation and use of cover crops to reduce drought effects. Weather advisory services were provided to farmers on daily basis through Kisan Mobile Advisory. KVK also organized technology demonstrations and trainings, celebrated technology weeks to educate the farmers on drought management About 921 extension programmes comprising meetings, field days, goshthis, farmers fairs, exhibitions and film shows were organized on drought-mitigation strategies with the participation of about 59660 farmers and extension personnel of the district that encountered drought. During the year, seeds of short-duration and drought tolerant varieties of crops were provided to the extent of 994.46 quintal sufficient to cover an area of 2920.5 ha benefiting 4505 farmers in these droughts hit areas. The technologies resulted in better moisture management, better crop establishment and growth, less frequent crop failures and raised crop yields.
\end{abstract}

Key Words : Climate change, Rainfall, Drought, Mitigation, Short duration varieties, Resource conservation technologies

View Point Article : Negi, R.S., Kaushik, S.S., Gurjar, P.S., Sharma, A.K. and Gautam, U.S. (2014). Drought mitigation interventions of Krishi Vigyan Kendra for enhancing chances of successful harvest in rainfed areas of Satna district of Madhya Pradesh. Internat. J. agric. Sci., 10 (1): 1-7.

Article History : Received : 20.10.2012; Revised : 01.09.2013; Accepted : 01.10 .2013

\footnotetext{
* Author for correspondence

${ }^{1}$ Deendayal Research Institute, Krishi Vigyan Kendra, SATNA(M.P.) INDIA(Email : rsnegi007@ rediffmail.com)
} 